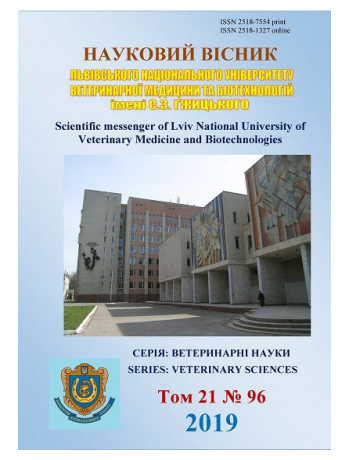

\author{
Науковий вісник Дьвівського національного університету \\ ветеринарної медицини та біотехнологій імені С.3. Гжицького. \\ Серія: Ветеринарні науки
}
Scientific Messenger of Lviv National University of Veterinary Medicine and Biotechnologies. Series: Veterinary sciences

\title{
Veterinary and sanitary evaluation of rabbit as an important reserve of dietary products
}

\author{
V.A. Kotelevych \\ Zhytomyr National Agroecological University, Zhytomyr, Ukraine
}

Article info

Received 04.10.2019

Received in revised form 03.11 .2019

Accepted 04.11.2019

Zhytomyr National Agroecological University, Korolova Str., 39, Zhytomyr, 10025, Ukraine Tel.: +38-067-456-23-80 E-mail:valya.kotelevich@ukr.net
Kotelevych, V.A. (2019). Veterinary and sanitary evaluation of rabbit as an important reserve of dietary products. Scientific Messenger of Lviv National University of Veterinary Medicine and Biotechnologies. Series: Veterinary sciences, 21(96), 58-64. doi: 10.32718/nvlvet9610

The purpose of the study was to perform a comparative veterinary sanitary examination and vetting the rabbit meat of two breeds, depending on the time of year. The subject of the study was 4-month-old male rabbits raised in the private farm, certified with California matured breeds and a Belgian giant (Flanders). According to the principle of analogues, 4 groups of rabbits of 6 heads were formed (2 each in springsummer and autumn-winter seasons). Before slaughter was determined - the index of abrasion (girth by shoulder blades, divided by the length of the trunk and multiplied by 100\%). Carried out anatomical section of carcasses and determined the output of meat. Then they carried out veterinary-sanitary examination by conventional methods. Biochemical studies of meat samples were performed 12 hours after slaughter at storage at $0-+2{ }^{\circ} \mathrm{C}$. Chemical analysis of the samples included determination of the water content, total protein, ash and macronutrients: Calcium (oxalate method), Phosphorus (photocolorimetric method by A.Yu. Levitsky in AT Usovich's modification). The results were statistically processed using a MS Excel 2003 computer program using a Student's t-test table. The 4-month-old rabbit meat is of California matured breeds and the Belgian giant (flanders) has high, almost equivalent, organoleptic-tasting characteristics. In terms of taste, tenderness, juiciness, color and aroma, the overall average score in the spring-summer and autumn-winter periods, respectively, was: California maturity - 4.7-4.8, and 4.6-4.7; Belgian Giant (Flanders) - 4.8-5.0 and 4.7-4.8 points. The broth of experimental rabbit meat had a delicate, sophisticated aroma and taste, good transparency and received the following points on a 5-point system: California matured and flanders in spring and summer - 5.0, in autumn and winter - 4.8 points. A comparative analysis of the breed characteristics of the studied rabbit identical samples revealed that the Belgian giant (flanders) has the highest moisture-holding capacity in the spring-summer period. The amount of bound water in the muscles of 4-month-old rabbits of the Flanders breed is slightly higher, so it will be more tender and juicy after cooking. The highest slaughter yield was determined in 4-month-old rabbits of the Belgian giant (flanders) and Californians reared in the spring-summer period, respectively - 56.51 $\pm 0.2 \%$ and $0.75 \pm 0.63 \%(P \leq 0.001)$. Among the 2 breeds of 4-month-old rabbits, the largest live and slaughter weights reached the rabbits grown in spring and summer (respectively: Belgian giant - $3375 \pm 27.0 \mathrm{~g}$ and $1912.03 \pm 19.4 \mathrm{~g} ;$ Californians $-2956.5 \pm 6.74 \mathrm{~g}$ and $1502.48 \pm 5.89 \mathrm{~g}(P \leq 0.001)$. The amount of nutrients in rabbit depends on the breed and time of year. The lowest protein content is found in the meat of 4-monthold rabbits of the California maturing breed period) $-15.47 \pm 0.58 \%$, and the highest - in 4-month flanders (spring-summer period) - $23.02 \pm 0.78 \%(P \leq 0.05)$. not, however, more meaty and less calorie meat is rabbit california matured breed, regardless of the time of year.

Key words: rabbits, Californian matured, Belgian giant (flanders), slaughter output, live weight.

\section{Ветеринарно-санітарна оцінка кролятини як важливого резерву дістичної продукції}

\author{
В.А. Котелевич
}


Житомирський національний агроекологічний університет, м. Житомир, Украӥна

Метою досліджень було проведення порівняльної ветеринарно-санітарної еспертизи та ветсаноиінки м'яса кролів двох порід залежно від пори року. Об'єктом досліджень були кролі-самиі віком 4 місяиі, вирощені у приватному господарстві, сертифіковані за породами каліфорнійська скоростигла та бельгійський велетень (фландр). За принципом аналогів було сформовано 4 групи кролів по 6 голів ( по 2 у весняно-літню та осінньо-зимову пори року). Перед забоєм визначали - індекс збитості (обхват за лопатками, поділений на довжину тулуба і помножений на 100\%). Проводили анатомічний розділ тушок і визначали вихід м'яса. Потім проводилиї ветеринарно-санітарну експертизу за загальноприйнятими методами. Біохімічні дослідження проб м'яса проводили через 12 годин після забою при зберіганні за температури $0-+2{ }^{\circ}$ С. Хімічний аналіз зразків включав визначення вмісту води, загального білка, золи та макроелементів: Кальиію (оксалатним методом), Фосфору (фотоколориметричним методом А.Ю. Левицького у модифікаиії А.Т. Усовича). Отримані результати обробляли статистично за допомогою комп'ютерної програми MS Excel 2003, використовуючи табличю t-критеріїв Стьюдента. М'ясо кролів 4-місячного віку порід каліфорнійська скоростигла та бельгійський велетень (фландр) має високі, практично рівноцінні, органолептично-дегустаційні характеристики. 3 а смаком, ніжністю, соковитістю, кольором та ароматом загальний середній бал у весняно-літній та осінньо-зимовий періоди відповідно становив: каліфорнійська скоростигла - 4,7-4,8, i 4,6-4,7; бельгійський велетнь (фландр) - 4,8-5,0 і 4,7-4,8 балів. Бульйон з м'яса піддослідних кролів мав ніжний, витончений аромат та смак, добру прозорість $і$ отримав такі бали за 5-бальною системою: каліфорнійська скоростигла і фландри у весняно-літній період - 5,0, в осінньо-зимовий - 4,8 бала. Порівняльний аналіз породних особливостей досліджуваних тотожних проб кролятини показав, ще найвищу вологоутримуючу здатність має м'ясо бельгійського велетня (фландра) у весняно-літній період. Кількість зв'язаної води у м'язах 4-місячних кролів породи фландр дещо вища, а отже, після кулінарної обробки воно буде більш ніжне та соковите. Найбільший забійний вихід визначено у 4-місячних кролів породи бельгійський велетень (фландр) та у каліфорнійців, вирощених у весняно-літній період, відповідно - 56,51 $\pm 0,2 \% i$ $0,75 \pm 0,63 \%(P \leq 0,001)$. Серед 2-ох порід 4-місячних кролів найбільшої жсивої та забійної ваги досягли кролі, вирощені у веснянолітній період (відповідно: бельгійський велетень - $3375 \pm 27,0$ г та 1912,03 \pm 19,4 г; каліфорнійці - 2956,5 \pm 6,74 г та 1502,48 \pm 5,89 $2(P \leq 0,001)$. Кількість поживних речовин в кролятині залежить від породи та пори року. Найменший вміст протеїну встановлено в м'ясі 4-місячних кролів каліфорнійської скоростиглої породи (осінньо-зимовий період) - 15,47 \pm 0,58\%, а найвищий - у 4місячних фландрів (весняно-літній період) - 23,02 \pm 0,78\% (P $\leq 0,05)$. М'ясо кролів обох порід високоякісне, однак більш дієтичним $i$ мени калорійним є м'ясо кролів каліфорнійської скоростиглої породи незалежно від пори року.

Ключові слова: кролі, каліфорнійська скоростигла, бельгійський велетень (фландр), забійний вихід, жива маса.

\section{Вступ}

Кролятина вважається високоцінним дієтичним продуктом і належить, як і курятина, до білого м'яса, чому сприяє високий вміст повноцінних білків, екстрактивних речовин, невелика кількість жиру та холестерину. Хімічний склад м'яса кроликів залежить від об'єктивних факторів (віку, статі, породи) та суб'єктивних (рівня годівлі, способу утримання, перенесених хвороб та вжитих лікарських засобів, технології забою тощо) (Kotelevych et al., 2011; Kotelevych \& Nevmerzhytska, 2013; Kotelevych, 2016; Darmohray et al., 2017; Ivanitskaya et al., 2017). Специфічний приємний запах і смак, притаманний м'ясу кролів, обумовлюється відносно високим (до 1,5-2,0\% в сирому м'ясі) вмістом азотистих екстрактивних речовин (креатиніну, карнозину, пуринових основ, інозинової кислоти та інших). Серед безазотистих екстрактивних речовин найбільше значення мають глікоген, цукри та кислоти, які під час варіння переходять в бульйон і справляють позитивний вплив на секреторну діяльність залоз травних органів людини. Біологічна цінність кролятини обумовлена не лише високим рівнем протеїну, а й найкращим співвідношенням повноцінних і неповноцінних білків. В білках сполучної тканини вміщується лише 14\% замінної амінокислоти оксипроліну, яка відсутня в повноцінних білках. Найкращими дієтичними властивостями володіє м'ясо кролів до 120-135-денного віку незалежно від статі. В кролятині є всі незамінні амінокислоти. Важливість вмісту незамінних амінокислот у продуктах харчування людини пояснюється їхніми функціями в організмі. Так, валін бере участь у функціонуванні центральної нервової системи, підтримує м'язовий тонус; фенілаланін та тирозин допомагають у синтезі гормонів тироксину й адреналіну, метіонін та цистин контролюють обмін сірки. За вмістом незамінних та дикарбонових амінокислот кролятина подібна до м'яса птахів і перевершує м'ясо багатьох інших видів тварин. При високому вмісті повноцінного білка м'ясо кролів водночас порівняно низькокалорійне, що особливо важливо для дітей, людей старшого віку та тих, які швидко набирають вагу. Якщо в 100 г кролятини 168 Ккал, то в 100 г яловичини 274-335 Ккал, баранини - 319 Ккал, свинини 389 Ккал. Отже, важливою перевагою кролятини є те, що вона -низькокалорійний продукт (Mishanin \& Kuc, 2003; Kalashnik \& Omel'chenko, 2004; Plotnikov, 2004; Aleksandrova \& Kosova, 2005; Carabaño et al., 2010; Sychov et al., 2018; Kotelevych, 2018).

Останнім часом медиків все більше непокоїть захворюваність людей різного віку атеросклерозом, гепатитом, холециститом, в основі яких часто лежить дисбаланс поживних речовин в організмі, порушення жирового обміну. Кролятина найкраще відповідає завданню підвищення повноцінності білкового живлення i зниження в раціоні рівня жирів, особливо насичених. В 100 г кролятини є всього 25 мг холестерину, проте наявний ліпоїд лецитин, який стримує синтез холестерину. Кролячий жир дуже цінний у біологічному плані. Відомий позитивний протекторний вплив жирних ненасичених кислот при перших симптомах серцево-судинних захворювань, оскільки вони володіють здатністю знижувати концентрацію холестерину в плазмі крові. Також поліненасичені жирні кислоти беруть участь у транспорті ліпідів 3 печінки, створенні сполучної тканини, є структурним компонентом клітин (мітохондрі-альних мембран) та 
ферментних систем. Внутрішній жир кроликів - біоактивна речовина, яка використовується як пом'якшувальний, протисвербіжний та антиалергійний засіб. Кролятина багата на вітаміни, особливо на вітамін Е (природний антиоксидант), з яким пов'язана не лише висока харчова і біологічна цінність м'яса, а й запобігання зниженню його якості при зберіганні. Тому м'ясо кролів витримує загальноприйняті терміни зберігання за різних температурних режимів. М'ясо кроля багате також вітаміном РР та вітамінами групи В (Mishanin \& Kuc, 2003; Plotnikov, 2004; Kotelevych et al., 2006; 2007; 2016; Kucheriavyi et al., 2016). Це робить кролятину ще поживнішою для людини, оскільки достатнє надходження вітаміну $\mathrm{B}_{6}$ в організм людини гарантує білковий обмін, бере участь в обміні речовин нервової системи і як кофермент бере участь у понад 100 ферментних реакціях. У м'ясі кролів вітамін В $_{6}$ зв'язаний з білком і легко засвоюється. Достатнє надходження вітаміну $\mathrm{B}_{12} 3$ їжею важливо для тканин $з$ високим ступенем оновлення. Кролятина може забезпечити щоденну потребу у вітаміні $\mathrm{B}_{6}$ на $30 \%$ i у вітаміні $\mathrm{B}_{12}$ - понад $60 \%$ (Mishanin \& Kuc, 2003). Кролятину варто вживати при найсуворіших дієтах: гастрити 3 підвищеною та пониженої кислотністю, виразкова хвороба шлунка та 12-палої кишки, різноманітні коліти, захворювання печінки та жовчних шляхів, нирок, гіпертонічна хвороба, цукровий діабет та уремія. У зв'язку з тим, що вона багата на білки, іiі рекомендують давати насамперед дітям, вагітним та жінкам, які годують грудьми. За результатами досліджень (Kotelevych et al., 2011; Kotelevych, 2016), вміст радіонуклідів в м'ясі кролів, що вирощувалися на забруднених внаслідок аварії на ЧАЕС радіонуклідами територіях у потерпілих районах Житомирської області, є дуже низький. Питома активність м'яса кролів 4-місячного віку була на рівні $8,8 \pm 0,8$ Бк/кг за вмістом цезію- 137 и $3,5 \pm 0,7$ Бк/кг за вмістом стронцію - 90, у м'ясі дорослих кролів ці показники відповідно становили $12,3 \pm 1,2$ та 8,2 \pm 1,5 Бк/кг (при нормі 200 Бк/кг і 20 Бк/кг).

Таким чином, кролятина - високоцінний дієтичний продукт, що утримує високий вміст повноцінних білків, екстрактивних речовин, невелику кількість жиру та холестерину. Серед усіх видів м'яса кролятина за білковою поживністю, соковитістю, ніжністю, смаком і засвоюваністю займає одне з перших місць. При оцінці кулінарних властивостей за стобальною шкалою бройлерні курчата отримують п'ятдесят, кращі сорти беконної свинини - шістдесят, яловичина - сімдесят п'ять, а кролятина - вісімдесят три бали, кращі показники тільки в індички. За матеріалами польських вчених, показник біологічної цінності кролятини складав 80 одиниць, свинини - 70 і яловичини - 69 (Barabash, 2004).

Враховуючи вищенаведене, метою наших досліджень було проведення комплексної порівняльної ветеринарно-санітарної експертизи та ветсаноцінки кролятини двох порід залежно від пори року.

\section{Матеріал і методи досліджень}

Об'єктом виробничих досліджень були кролісамці віком 4 місяці, вирощені у приватному господарстві с. Глибочиця, сертифіковані за породами каліфорнійська скоростигла, бельгійський велетень (фландр). Для дослідження було сформовано за принципом аналогів 4 групи кролів по 6 голів (по дві у весняно-літню та осінньо-зимову пори року). Перед забоєм визначали індекс збитості (рис. 1-2) (обхват за лопатками, поділений на довжину тулуба і помножений на 100\%). Забій тварин проводився в умовах приватного господарства із дотриманням ветеринарносанітарних вимог. Анатомічний розділ тушок починали після зняття шкурки разом із підшкірним жиром та відділення голови на рівні першого хребця, передні лапи відокремили по зап'ясні, задні по скакальні суглоби. Надалі проводили потрошіння тушки: розрізали черевну стінку по білій лінії, перерізали лонне зрощення, видаляли сечовий міхур, видаляли кишечник та шлунок із відділеною раніше прямою кишкою, виймали печінку. Розрізавши діафрагму, видалили легені, серце, трахею та стравохід. Ветеринарносанітарну експертизу проводили на кафедрі паразитології, ветеринарно-санітарної експертизи та зоогігієни ЖНАЕУ (рис. 3) за загальноприйнятими методами. М'язову тканину, відділивши від кісток, зважували окремо за групами: тазо-стегнова, шийно-грудна, попереково-куприкова, лопатко-плечова. Окремо зважували їстівні частини тушок: серце, печінку, легені, нирки, внутрішній жир та неїстівні: голову, кістки. Виміряли масу кісток та м'яса. На основі результатів анатомічного розділу визначали відношення маси м'язів до маси кісток, співвідношення окремих груп м'язів і обмускуленість тушки. Після анатомічного розділу відбирали по дві проби м'язів із задньої частини від кожної тушки для біохімічних та хімічних досліджень. Проводили визначення органолептичних показників м'яса кролів шляхом сенсорного аналізу якості тушок та дослідження відвареного м'яса і бульйону за 5-бальною шкалою. Біохімічні дослідження проб м'яса проводили через 12 годин після забою при зберіганні за температури $0-+2{ }^{\circ} \mathrm{C}$. Визначали $\mathrm{pH}$, вологоутримуючу здатність, ставили реакції бульйону 3 реактивом Несслера та сірчанокислою міддю. Хімічний аналіз зразків проводили за загальноприйнятими методиками на вміст: води, загального білка, золи. Вміст макроелементів: Кальцію (оксалатним), Фосфору (фотоколориметриметричним) методом А.Ю. Левицького у модифікації А.Т. Усовича.

Отримані результати оброблені статистично за допомогою комп'ютерної програми MS Excel 2003, використовуючи таблицю t-критеріїв Стьюдента. 


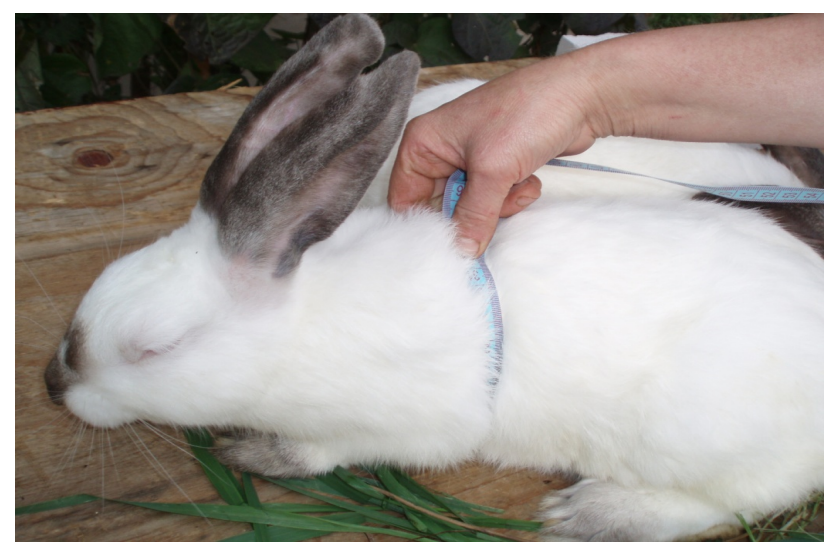

Рис. 1. Вимірювання обхвата за лопатками

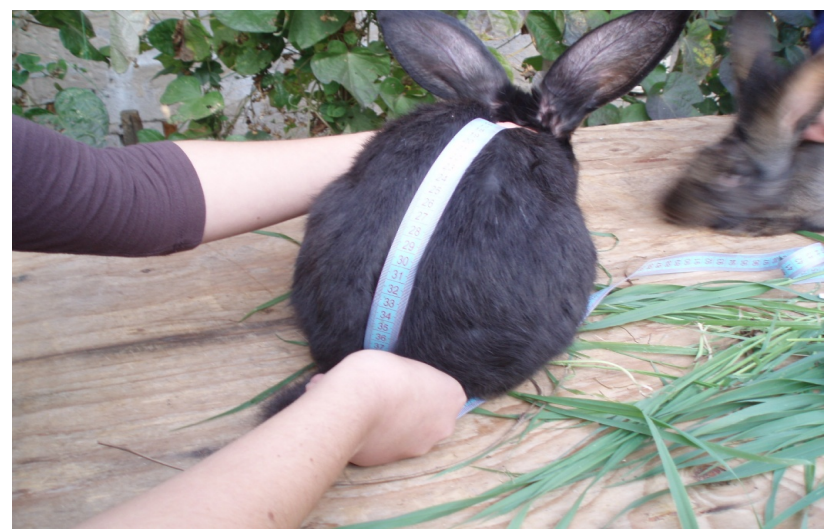

Рис. 2. Вимірювання довжини тулуба

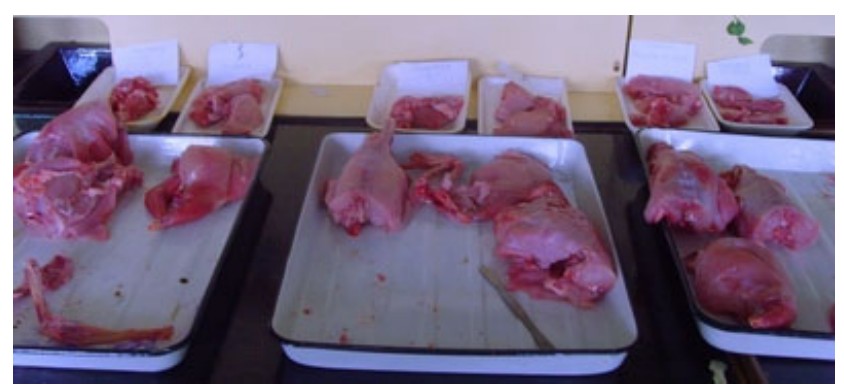

Рис. 3. Анатомічний розділ тушок і обвалка м’яса

\section{Результати та їх обговорення}

Проведеними дослідженнями встановлено, що у тушках кролів досліджуваних порід, які надходили 3 фермерського господарства, благополучного щодо інфекційних та інвазійних захворювань, патологоанатомічні зміни відсутні. М'язова тканина задньої частини тушок кролів, незалежно від породи та пори року утримання більш щільна та пружна, ніж м'язи передньої частини. М'язи тушки мають легкий специфічний запах, злегка вологі. Підшкірний жир дорослих кролів - молочно-білого кольору, іноді з легким рожевим відтінком, без стороннього запаху. Підшкірний жир молодих тварин - яскраво-білого кольору із легким специфічним запахом. Внутрішній жир у тварин всіх вікових груп білого кольору із яскравовираженим специфічним запахом. Огляд голів досліджуваних тушок визначав їх правильну конфігурацію, слизові оболонки цілісні, блискучі, блідо-рожевого кольору. Огляд внутрішніх органів не виявив ознак патологічних процесів та перенесених хвороб. Печінка щільна, червоно-коричневого кольору, не збільшена. Всі взяті на дослідження тушки кролів - першої категорії. За результатами проведеної комісійної органолептичної оцінки проб м'яса кролів 4-місячного віку порід каліфорнійська скоростигла та бельгійський велетень (фландр) має високі, практично рівноцінні, органолептично-дегустаційні характеристики. Бульйон з м'яса піддослідних кролів мав ніжний, витончений аромат та смак, добру прозорість і отримав такі бали за 5-бальною оцінкою (табл. 1).

За смаком, ніжністю, соковитістю, кольором та ароматом загальний середній бал кролятини наведено у табл. 2. М'ясо шийно-грудних відділків за соковитістю та ніжністю переважало м'ясо із поперековотазової частини.

Зниження $\mathrm{pH}$ м'яса кролів через 12 годин після забою за температури $0-+2{ }^{\circ} \mathrm{C}$ проходило повільно, що свідчило про накопичення молочної кислоти внаслідок розщеплення глікогену. Найнижчим було $\mathrm{pH}$ м'яса кролів каліфорнійської скоростиглої породи, тобто вміст глікогену в ньому дещо вищий, ніж у м'ясі їхніх аналогів - фландрів. Через 12 годин після забою при зберіганні кролятини за температури від 0 до $+2{ }^{\circ} \mathrm{C}$, бульйон 3 м'яса кролів за реакцією на аміак та $з$ сірчанокислою міддю - свіжий, а м'ясо кролів до 4-місячного віку володіє високою вологоутримуючою здатністю (табл. 3).

\section{Таблиця 1}

Органолептичні показники бульйону із м’яса кролів спеціалізованих м'ясних порід у 4-місячному віці (n = 6)

\begin{tabular}{|c|c|c|c|c|c|c|}
\hline Міцність & Наваристість & Аромат & Колір & Смак & Прозорість & $\begin{array}{c}\text { Загальна сума балів } \\
\text { (середня) }\end{array}$ \\
\hline \multicolumn{7}{|c|}{ Каліфорнійська скоростигла, бельгійський велетень (весняно-літній період) } \\
\hline Добра & відмінна & $\begin{array}{c}\text { сильно } \\
\text { виражений }\end{array}$ & $\begin{array}{c}\text { добре } \\
\text { виражений }\end{array}$ & дуже приємний & прозорий & 5,0 \\
\hline \multicolumn{7}{|c|}{ Каліфорнійська скоростигла, бельгійський велетень (осінньо-зимовий період) } \\
\hline Добра & добра & виражений & виражений & дуже приємний & прозорий & 4,8 \\
\hline
\end{tabular}


Таблиця 2

Органолептичні показники м’яса кролів спеціалізованих м’ясних порід у 4-місячному віці $(\mathrm{n}=6)$

\begin{tabular}{|c|c|c|c|c|c|c|}
\hline М'язи & Ніжність & Соковитість & Аромат & Смак & Колір & $\begin{array}{c}\text { Загальний бал } \\
\text { (середній) }\end{array}$ \\
\hline \multicolumn{7}{|c|}{ Каліфорнійська скоростигла (весняно-літній період) } \\
\hline шийно-грудні & $\begin{array}{l}\text { досить } \\
\text { м'яке }\end{array}$ & $\begin{array}{c}\text { дуже } \\
\text { соковите }\end{array}$ & сильно виражений & $\begin{array}{c}\text { яскраво вираже- } \\
\text { ний }\end{array}$ & $\begin{array}{c}\text { добре поміт- } \\
\text { ний }\end{array}$ & 4,7 \\
\hline $\begin{array}{c}\text { попереково- } \\
\text { тазові } \\
\end{array}$ & м’яке & соковите & сильно виражений & добрий & помітний & 4,8 \\
\hline \multicolumn{7}{|c|}{ Бельгійський велетень (весняно-літній період) } \\
\hline шийно-грудні & дуже м'яке & $\begin{array}{c}\text { дуже } \\
\text { соковите }\end{array}$ & сильно виражений & $\begin{array}{c}\text { яскраво вираже- } \\
\text { ний }\end{array}$ & $\begin{array}{c}\text { добре поміт- } \\
\text { ний }\end{array}$ & 4,8 \\
\hline $\begin{array}{c}\text { попереково- } \\
\text { тазові } \\
\end{array}$ & м’яке & $\begin{array}{c}\text { дуже } \\
\text { соковите }\end{array}$ & сильно виражений & $\begin{array}{c}\text { яскраво вираже- } \\
\text { ний } \\
\end{array}$ & $\begin{array}{c}\text { добре поміт- } \\
\text { ний } \\
\end{array}$ & 5,0 \\
\hline \multicolumn{7}{|c|}{ Каліфорнійська скоростигла (осінньо-зимовий період) } \\
\hline шийно-грудні & м’яке & соковите & виражений & виражений & помітний & 4,6 \\
\hline $\begin{array}{c}\text { попереково- } \\
\text { тазові }\end{array}$ & м'яке & соковите & виражений & виражений & помітний & 4,7 \\
\hline \multicolumn{7}{|c|}{ Бельгійський велетень (осінньо-зимовий період) } \\
\hline шийно-грудні & $\begin{array}{l}\text { досить } \\
\text { м'яке }\end{array}$ & соковите & $\begin{array}{c}\text { сильно } \\
\text { виражений }\end{array}$ & виражений & помітний & 4,7 \\
\hline $\begin{array}{c}\text { попереково- } \\
\text { тазові }\end{array}$ & м’яке & соковите & виражений & виражений & помітний & 4,8 \\
\hline
\end{tabular}

Таблиця 3

Показники вологоутримуючої здатності м'яса 4-місячних кролів залежно від породи та пори року $(\mathrm{M} \pm \mathrm{m}, \mathrm{n}=6$; $\mathrm{P} \leq 0,05)$

\begin{tabular}{lcccc}
\hline \multicolumn{1}{c}{ Показники } & \multicolumn{2}{c}{ Каліфорнійська порода } & \multicolumn{2}{c}{ Бельгійський велетень (фландр) } \\
\cline { 2 - 5 } & весна-літо & осінь-зима & весна-літо & осінь-зима \\
\hline $\begin{array}{l}\text { Вміст зв'язаної води, \% до } \\
\text { маси м'яса (3ВМ) }\end{array}$ & $63,9 \pm 0,68$ & $63,87 \pm 0,65$ & $67,1 \pm 0,67$ & $66,7 \pm 0,64$ \\
$\begin{array}{l}\text { Вміст зв'язаної води, \% до } \\
\text { загальної вологи (ЗВВ) }\end{array}$ & $82,38 \pm 0,45$ & $81,56 \pm 0,38$ & $97,17 \pm 0,87$ & $96,23 \pm 0,78$ \\
\hline
\end{tabular}

Результати оцінки м'ясної продуктивності досліджуваних кролів наведені в таблиці 4. Найбільші жива і забійна маса та забійний вихід м'якоті визначено у 4-місячних кролів обох порід у весняно-літній період (табл. 5). Серед 4-місячних кролів найбільшу абсолютну масу м'якоті мають фландри веснянолітнього періоду. Відносна ж маса м'якоті у фландрів весняно-літнього та осінньо-зимового періодів практично рівноцінна. Із збільшенням м'язової маси при інтенсивному способі вирощування кролів до 4-місячного віку зростає i абсолютна маса кісток, проте зменшується відносна.
Жива маса серед скоростиглих порід кролів у 4-місячному віці у весняно-літній період року була вищою, ніж в осінньо-зимовий, а у фландрів - вища, ніж у їхніх аналогів каліфорнійської породи (табл. 6).

Показники забійного виходу бельгійського велетня (весняно-літнього періоду) $є$ максимально наближеними до еталонних скоростиглих порід кролів I-ї категорії вгодованості, за якими забійний вихід спеціалізованих м'ясних порід у 4-місячному віці може сягати від 50 до $56 \%$.

\section{Таблиця 4}

Оцінка м'ясної продуктивності 4-місячних кролів $(\mathrm{M} \pm \mathrm{m}, \mathrm{n}=6 ; \mathrm{P} \leq 0,05)$

\begin{tabular}{lrrr}
\hline \multirow{2}{*}{ Показники } & \multicolumn{2}{c}{ Каліфорнійська порода } & \multicolumn{2}{c}{ Бельгійський велетень (фландр) } \\
\cline { 2 - 4 } & весна-літо & осінь-зима & весна-літо \\
\hline Обхват за лопатками, см & $31,25 \pm 0,25$ & $30,7 \pm 0,34$ & $33,25 \pm 0,14$ \\
Довжина тулуба, см & $40,00 \pm 0,02$ & $38,56 \pm 0,31$ & $32,32 \pm 0,27$ \\
Індекс збитості & $78,73 \pm 1,18$ & $79,74 \pm 1,22$ & $71,93 \pm 0,15$ \\
Площа мускульного очка, см $^{2}$ & $8,18 \pm 0,19$ & $7,79 \pm 0,12$ & $77,07 \pm 0,36$ \\
\hline
\end{tabular}


Таблиця 5

Морфологічний склад тушок 4-місячних кроликів залежно від пори року $(\mathrm{M} \pm \mathrm{m}, \mathrm{n}=6 ; \mathrm{P} \leq 0,05)$

\begin{tabular}{|c|c|c|c|c|}
\hline \multirow{2}{*}{ Показники } & \multicolumn{2}{|c|}{ Каліфорнійська порода } & \multicolumn{2}{|c|}{ Бельгійський велетень (фландр) } \\
\hline & весна-літо & осінь-зима & весна-літо & осінь-зима \\
\hline Забійна маса тушки, г & $1502,48 \pm 5,89$ & $1459,29 \pm 17,94$ & $1912,03 \pm 19,4$ & $1590,3 \pm 3,0$ \\
\hline Маса м'якоті без кісток, г & $1235,75 \pm 5,53$ & $1178,78 \pm 9,83$ & $1585,65 \pm 19,6$ & $1318,2 \pm 2,8$ \\
\hline Вихід м’якоті, \% & $82,21 \pm 0,41$ & $80,79 \pm 0,35$ & $82,91 \pm 0,23$ & $82,9 \pm 0,56$ \\
\hline \multicolumn{5}{|c|}{ Маса м'якоті анатомічних частин тушки, \% до загальної маси м'якоті тушки: } \\
\hline плечо-лопаткової & $16,09 \pm 0,16$ & $17,83 \pm 0,13$ & $13,74 \pm 0,36$ & $17,63 \pm 0,13$ \\
\hline тазо-стегнової & $31,35 \pm 0,52$ & $35,62 \pm 0,48$ & $29,71 \pm 0,38$ & $33,75 \pm 0,21$ \\
\hline шийно-грудної & $26,61 \pm 0,31$ & $20,91 \pm 0,22$ & $27,15 \pm 0,42$ & $26,26 \pm 0,38$ \\
\hline попереково-куприкової & $28,5 \pm 0,66$ & $25,65 \pm 0,62$ & $29,63 \pm 0,32$ & $28,43 \pm 0,31$ \\
\hline \multicolumn{5}{|c|}{ Відносна маса анатомічних частин тушки, \% до маси м'ясної тушки: } \\
\hline плечо-лопаткової & $14,88 \pm 0,02$ & $16,39 \pm 0,05$ & $13,45 \pm 0,24$ & $14,17 \pm 0,22$ \\
\hline тазо-стегнової & $34,08 \pm 0,51$ & $32,97 \pm 0,31$ & $28,88 \pm 0,31$ & $33,41 \pm 0,34$ \\
\hline шийно-грудної & $27,65 \pm 0,13$ & $24,71 \pm 0,11$ & $29,06 \pm 0,28$ & $27,47 \pm 0,21$ \\
\hline попереково-куприкової & $25,45 \pm 0,37$ & $26,17 \pm 0,41$ & $29,24 \pm 0,19$ & $28,81 \pm 0,22$ \\
\hline \multicolumn{5}{|c|}{ Відносна маси м'якоті до кісток за анатомічними частинами тушки,\% } \\
\hline плечо-лопаткової & $879,38 \pm 12,06$ & $846,17 \pm 11,43$ & $878,99 \pm 19,83$ & $851,13 \pm 18,2$ \\
\hline тазо-стегнової & $847,23 \pm 19,78$ & $814,95 \pm 20,94$ & $860,28 \pm 13,62$ & $829,78 \pm 18,4$ \\
\hline шийно-грудної & $351,54 \pm 8,94$ & $326,4 \pm 8,88$ & $459,79 \pm 8,44$ & $422,17 \pm 8,15$ \\
\hline попереково-куприкової & $493,61 \pm 20,46$ & $453,5 \pm 21,61$ & $547,77 \pm 21,3$ & $509,86 \pm 21,1$ \\
\hline
\end{tabular}

\section{Таблиця 6}

Міжпородні особливості пілязабійних показників 4-місячних кролів залежно від породи та пори року $(\mathrm{M} \pm \mathrm{m}, \mid$ $\mathrm{n}=6 ; \mathrm{P} \leq 0,05)$

\begin{tabular}{lcccc}
\hline \multicolumn{1}{c}{ Показники } & \multicolumn{2}{c}{ Каліфорнійська порода } & \multicolumn{2}{c}{ Бельгійський велетень (фландр) } \\
\cline { 2 - 5 } Жесінь-зима & весна-літо & осінь-зима \\
\hline Жива маса перед забоєм, г. & $2956,6 \pm 6,74$ & $2940,0 \pm 48,48$ & $3375,0 \pm 27,0$ & $3129,5 \pm 4,02$ \\
Маса шкурки, г & $498,6 \pm 12,02$ & $487,7 \pm 12,59$ & $451,05 \pm 4,9$ & $522,7 \pm 3,9$ \\
Забійна маса тушки, г & $1502,48 \pm 5,89$ & $1459,29 \pm 17,94$ & $1912,03 \pm 19,4$ & $1590,3 \pm 3,1$ \\
Забійний вихід, \% & $50,75 \pm 0,63$ & $49,65 \pm 0,55$ & $56,51 \pm 0,2$ & $50,83 \pm 0,61$ \\
Маса серця, легень та печінки, г & $150 \pm 1,42$ & $137,93 \pm 5,58$ & $168 \pm 2,48$ & $169 \pm 2,8$ \\
Маса анатомічних частин тушки, г: & & & \\
Плечо-лопаткової & $223,55 \pm 1,66$ & $237,65 \pm 1,77$ & $235,85 \pm 7,0$ & $223,08 \pm 1,65$ \\
Тазо-стегнової & $511,1 \pm 3,24$ & $478,38 \pm 6,27$ & $553,73 \pm 10,3$ & $511,9 \pm 2,8$ \\
Шийно- грудної & $415,5 \pm 3,06$ & $356,63 \pm 6,6$ & $550,13 \pm 2,6$ & $419,8 \pm 2,18$ \\
Попереково-куприкової & $352,4 \pm 3,54$ & $379,93 \pm 6,73$ & $553,7 \pm 2,6$ & $435,5 \pm 3,67$ \\
\hline
\end{tabular}

За результатами наших досліджень, кількість поживних речовин в кролятині залежать від породи та пори року. Найменший вміст протеїну встановлено в м'ясі 4-місячних кролів каліфорнійської скоростиглої породи (осінньо-зимовий період) $-15,47 \pm 0,58 \%$, а найвищий - у 4-місячних фландрів (весняно-літній період) $-23,02 \pm 0,78 \%(\mathrm{P} \leq 0,05)$. Вміст жиру у м'якоті 4-місячних кролів каліфорнійської скоростиглої породи в осінньо-зимовий період складає 6,69 \pm 0,13\%. Менш інтенсивно проходить накопичення жиру в м'язах 4-місячних фландрів весняно-літнього періоду $-5,91 \pm 0,06 \%$, особливо порівняно з вмістом жиру в осінньо-зимовий період) $-8,86 \pm 0,08 \%$ (P $\leq$ $0,05)$. Значний, як для 4-місячних кролів, вміст жиру у м'язах фландрів (осінньо-зимовий період) сприяв підвищеному рівню калорійності $(651,16 \pm 6,7$ кДж/ 100 г). За результатами наших досліджень, м'ясо 4місячних кролів каліфорнійської скоростиглої породи, вирощених у весняно-літньому та осінньо-зимовому періодах за калорійністю є практично рівноцінними (503 \pm 9,6 кДж/100 та 515,42 \pm 11,37 кДж/100г), а отже менш калорійне, ніж у їхніх аналогів фландрів.
Враховуючи породні, кормові, сезонні та ін. фактори, вміст Кальцію у м'язах загалом зростає. У 4-місячних кролів він коливається від 20,12 0,45 мг/100 г у м'язах фландрів (осінньо-зимовий період) до 31,42 \pm 6,41 мг/100 г (весняно-літній період); від 23,52 $\pm 2,1$ мг/100г у каліфорнійської скоростиглої породи (осінньо-зимовий період) до 25,46 \pm 3,11 мг/100г (весняно-літній період). Вміст Фосфору в м'ясі кролів бельгійський велетень (фландр) у весняно-літній період був на рівні 233,63 $\pm 1,12$ мг/100 г, осінньо-зимовий - 243,11 \pm 0,91 мг/100 г, у їх аналогів породи каліфорнійська скоростигла відповідно: весняно-літній період - 178,35 $\pm 1,08$ мг/100 г і осінньозимовий $-169,87 \pm 1,13$ мг/100 г.

\section{Висновки}

1. М'ясо кролів 4-місячного віку порід каліфорнійська скоростигла та бельгійський велетень (фландр) має високі, практично рівноцінні, органолептичнодегустаційні характеристики. Бульйон 3 м’яса піддос- 
лідних кролів мав ніжний, витончений аромат та смак, добру прозорість.

2. Забійний вихід, вихід м'язової тканини, обмускуленість тушок, вихід кісток в тушках кролів неоднакові й залежать від породних особливостей тварин та пори року вирощування. Найбільшої живої та забійної ваги досягли кролі, вирощені у весняно-літній період (відповідно: бельгійський велетень (фландр) $3375 \pm 27,0$ г та $1912,03 \pm 19,4$ г; каліфорнійці $2956,5 \pm 6,74$ г та $1502,48 \pm 5,89$ г $(\mathrm{P} \leq 0,05)$.

3. За хімічним складом, тобто за гармонійним співвідношенням білка, води та жиру, найбільш цінним $є$ м'ясо 4-місячних кролів породи бельгійський велетень (фландр) та каліфорнійської породи, вирощених у весняно-літній період. М'ясо всіх груп піддослідних кролів $є$ високоякісним та дієтичним.

4. У вирішенні проблеми дієтичного повноцінного харчування населення, особливо дітей та людей похилого віку, в екологічно небезпечних умовах навколишнього середовища кролятина має займати провідне місце.

Перспективи подальиих досліджень. Подальші дослідження будуть спрямовані на детальне вивчення особливостей та переваг ведення органічного кролівництва в сучасних умовах для підвищення економічної ефективності та пропаганди бройлерного кролівництва в господарствах усіх форм власності.

\section{References}

Aleksandrova, S.N., \& Kosova, T.I. (2005). Kroliki: Razvedenie, vyrashhivanie, kormlenie. Doneck : Stalker (in Russian).

Barabash, B.P. (2004). Vozrozhdenie zverovodstva v Pol'she. Krolikovodstvo i zverovodstvo, 6, 27-28 (in Russian).

Carabaño, R., Villamide, M.J., García, J., Nicodemus, N., Llórente, A., Chamorro, S., Menoyo, D., GarcíaRebollar, P., García-Ruiz, AJ., \& De Blas, J.C. (2010). New concepts and objectives for protein-amino acid nutrition in rabbits: a review. World Rabbit Science. 17(1), 1-14. doi: 10.4995/wrs.2009.664.

Darmohray, L., Luchyn, I., \& Gutyj, B. (2017). Influence of feeding management on productive indicators of rabbits for intensive growing technology. Scientific Messenger of LNU of Veterinary Medicine and Biotechnologies. 19(79), 38-43. doi: 10.15421/nvlvet7908.

Ivanitskaya, A., Lesyk, Y., Kropyvka, S., \& Hoivanovych, N. (2017). Growth and development of the organism rabbits for the feeding of the silicon connection. Scientific Messenger of LNU of Veterinary Medicine and Biotechnologies, 19(82), 8287. doi: $10.15421 /$ nvlvet 8217.

Kalashnik, O.V., \& Omel'chenko, N.V. (2004). Problemy vosstanovlenija krolikovodstva v Ukraine. Krolikovodstvo i zverovodstvo, 4, 30 (in Russian).
Kotelevych, V.A. (2016). Kroliatyna - vazhlyvyi rezerv orhanichnoi produktsii. Biobezpeka u tvarynnytstvi i ptakhivnytstvi: problemy ta yikh rishennia : materialy mizhnar. nauk.-prakt. konf. Mykolaiv: MNAU, 269275 (in Ukrainian).

Kotelevych, V.A. (2016). Rol krolivnytstva u rozvytku malykh form hospodariuvannia yak faktora sotsialnoekonomichnoi stabilnosti silskykh terytorii na samozainiatosti naselennia. Rol ahrarnykh vyshchykh navchalnykh zakladiv $u$ rozvytku malykh form hospodariuvannia yak faktora sotsialno-ekonomichnoi stabi-lnosti silskykh terytorii ta samozainiatosti naselennia : materialy Mizhnar. nauk.-prakt. konf. (23 lystop. 2016 r.). Kyiv, 16-18 (in Ukrainian).

Kotelevych, V.A. (2016). Vazhnyj rezerv organicheskoj produkcii - mjaso krolikov. Uchenye zapiski "Vitebskaja ordena "Znak Pocheta" Gos. akad. vet. Mediciny", 52(3), 137-140 (in Russian).

Kotelevych, V.A. (2018). Kroliatyna - vazhlyvyi rezerv m'iasa v Ukraini. Biolohiia tvaryn, 20(3), 128 (in Ukrainian).

Kotelevych, V.A., \& Nevmerzhytska, M.A. (2013). Yakist ta bezpeka miasa kroliv, vyroshchenykh u pryvatnomu sektori Korostenskoho raionu Zhytomyrskoi oblasti. Vet. medytsyna Ukrainy, 5, 2425 (in Ukrainian).

Kotelevych, V.A., Bondar, M.O., \& Mykhailenko, O.Ya. (2011). Kroliatyna - naikrashchyi kharchovyi produkt u zminenykh ekolohichnykh umovakh Poliskoho rehionu. Vet. medytsyna Ukrainy, 8, 36 (in Ukrainian).

Kotelevych, V.A., Fedotov, V.S., Feshchenko, D.V., \& Sakhno, N.P. (2006). Nezasluzheno zabutyi rezerv m'iasa v Ukraini. Suchasni problemy ekolohii: materialy III mizhvuz. konf. stud., asp. ta molodykh vchenykh (16-17 bereznia 2006 r.). Zhytomyr: ZhNAEU, 42-43 (in Ukrainian).

Kotelevych, V.A., Fedotov, V.S., Feshchenko, D.V., \& Sakhno, N.P. (2007). Veterynarno-sanitarna otsinka miasa kroliv zalezhno vid porody ta viku. Vet. medytsyna Ukrainy, 1, 32-34 (in Ukrainian).

Kucheriavyi, V., Shtenska, O., \& Vanzhula, Y. (2016). Morphological and biochemical blood values of fattening young rabbits. Scientific Messenger of LNU of Veterinary Medicine and Biotechnologies. 18, 2(67), 124-128. doi: 10.15421/nvlvet6728.

Mishanin, Ju.F., \& Kuc, R.Ju. (2003). Vitaminy v mjase krolikov i nutrij. Mjasnaja industrija, 1, 33-35 (in Russian).

Plotnikov, V.G. (2004). O poleznosti krol'chatiny. Krolikovodstvo i zverovodstvo, 4, 21 (in Russian).

Sychov, M.Yu., Holubieva, T.A., Pozniakovskyi, Yu.V., Andriienko, L.M., \& Holubiev, M.I. (2018). Productivity of growing rabbits at different levels of methionine in the diet. Scientific Messenger of Lviv National University of Veterinary Medicine and Biotechnologies. 20(84), 6064. doi: 10.15421/nvlvet8411. 